\title{
Spatial distribution of main clupeid species in relation to acoustic assessment surveys in the continental shelves of Senegal and The Gambia
}

\author{
Abdoulaye Sarré ${ }^{1, *}$, Jens-Otto Krakstad ${ }^{2}$, Patrice Brehmer ${ }^{1,3}$ and Ebou Mass Mbye ${ }^{4}$ \\ ${ }^{1}$ Centre de Recherche Océanographique de Dakar - Thiaroye (CRODT), BP 2241 Dakar, Sénégal \\ 2 Institute of Marine Research (IMR), P.O. Box 1870 Nordnes, NO-5817 Bergen, Norway \\ ${ }^{3}$ Institut de Recherche pour le Developpement (IRD), UMR 195 (CNRS, UBO, IRD, Ifremer) Lemar, Route des pères Mariste, BP1389 \\ Dakar, Sénégal \\ ${ }^{4}$ Ministry of Fisheries, Water Resources and National Assembly Matters, Gambia, Fisheries Department (FD), Banjul, The Gambia
}

Received 8 June 2017 / Accepted 12 December 2017

Guest Editor: Jörn Schmidt

\begin{abstract}
This work compiles hydroacoustic recordings and catch data over Senegambia (Senegal and The Gambia) from assessment surveys on the major clupeid species to identify sources of bias in abundance estimates caused by their horizontal distribution. The latitudinal distribution of small pelagic fish is often well known, while their "across shelf" distribution on the continental shelf is less understood. The southern part of the Senegambian shelf has a wide shallow water $(<10 \mathrm{~m})$ area that makes up $20 \%\left(1500 \mathrm{NM}^{2}\right)$ of the total shelf surface, while the northern part accounts for $3 \%\left(200 \mathrm{NM}^{2}\right)$. These areas are not assessed by conventional fisheries acoustics surveys and therefore increase the uncertainty of the assessment of these species. Our findings show that this likely introduces a bias in the assessment of Sardinella maderensis, while for $S$. aurita no major estimation-error is caused by their horizontal distribution. The data confirm that Ethmalosa fimbriata and Ilisha africana are challenging to assess by conventional surveys, due to their mostly inshore distribution. We emphasise the usefulness of assessing $S$. aurita through fisheries independent hydroacoustic surveys, and propose alternative methods to survey shallow water areas to reduce biases in biomass estimates and distribution mapping.
\end{abstract}

Keywords: Fish distribution / Ethmalosa fimbriata / Ilisha africana / Sardinella spp. / West Africa

\section{Introduction}

The marine waters off Northwest Africa are very productive because of active upwelling that takes place and supports important fish resources (Roy et al., 1992; Auger et al., 2016). Fisheries contribute on average more than $3 \%$ of the gross domestic product of Senegal, The Gambia, Mauritania and Morocco and play an important role in food security, employment and income (Ba et al., 2016). In Senegal, a few species of small pelagics make up the bulk of landings; these include sardinella (Sardinella aurita and S. maderensis), horse mackerel (Trachurus trecae and Caranx rhonchus), bonga shad (Ethmalosa fimbriata), chub mackerel (Scomber colias) and West African Ilisha (Ilisha africana). Of these, sardinella are the most important as the key food species for the Senegambian population (Senegal and The Gambia) (Thiaw

*Corresponding author: ablaysarrey@yahoo.fr et al., 2017), also bonga is an important food resource in much of West and Central Africa (Jallow, 1994), as is I. africana, which is usually smoked for local consumption (Fame et al., 2017). Acoustic surveys are the basic tool for biomass assessment of sardinella species, horse mackerels and chub mackerel (Simmonds and MacLennan, 2005), and provide indices of abundance used in the models to determine the state of their exploitation. They are performed by national (RV "Itaf Deme" (ID) in Senegal) or international research vessels (mainly the Norwegian RV "Dr Fridtjof Nansen" (DFN)), at sub-regional level. The continental shelf surveyed during these acoustic surveys can be divided in two separate regions north and south of Dakar respectively, based on their bathymetric characteristics. The northern shelf is narrow with the $25 \mathrm{~m}$ and $500 \mathrm{~m}$ isobaths located on average $5 \mathrm{NM}$ and $20 \mathrm{NM}$ distance from the coast, while in the southern shelf is wide with a large shallow water coastal region where the $25 \mathrm{~m}$ and $500 \mathrm{~m}$ isobath lie on average $20 \mathrm{NM}$ and $55 \mathrm{NM}$ from the coast. The main 
shortcomings of these surveys are their lack of continuity since 2006, and the representativeness of the stocks covered. The main aim of assessing the abundance of small pelagic fish in North West Africa was to cover the stocks of mature fish, assuming the major distribution area of our target species were covered by the surveys. In Senegambian waters, where both sardinella species occur, the shallow shelf covers a wide area between the coastline and the $10 \mathrm{~m}$ isobath. It is known that the distribution of some target species of these acoustic assessment surveys continue inshore of the investigated area. This applies especially to the inner shelf and the riverine systems between the Cap-Vert peninsula (Dakar) to Casamance (south Senegal). Several studies have been carried out in these systems, mainly utilising a boat with small draft, the "Diassanga" (DS), to assess the species composition and distribution of small pelagic fish (Albaret et al., 2004; Ecoutin et al., 2013; Sadio, 2015). These shallow areas are important spawning and nursery grounds for all the clupeid species (Diouf, 1996; Ndoye et al., 2014; Tiedemann and Brehmer, 2017) and are regarded as being of high biological importance (Sloterdijk et al., 2017). The Saloum and The Gambia River estuaries are the principal spawning areas (Panfili et al., 2004; Vidy et al., 2004). There are two main types of estuarine/riverine system in the area; the Casamance and Saloum estuaries which are "inverse estuaries" (Albaret, 1987; Guillard and Lebourges, 1998; Simier et al., 2004) with highest salinity up-river e.g. furthest inland, away from the ocean. The Gambia estuary, on the other hand is a classic river system (Albaret et al., 2004; Guillard et al., 2004; Simier et al., 2006), with lower salinity up-river and strong seasonality in salinity due to variations in river flow and rain. High salinities in The Gambia River are normally only recorded towards the end of the wet season and close to the sea, with a displacement upstream in the dry season (Albaret et al., 2004; Guillard et al., 2004). The distributions of clupeids are markedly different in these estuaries with highest concentrations of fish at the mouth of the normal estuary and few or no clupeids further upstream, while in the inverse estuaries (Albaret et al., 2004; Guillard et al., 2004), clupeids and in particular $S$. maderensis may be found far into the river systems at salinities up to 50 (Simier et al., 2004). S. maderensis is known to have high physiological adaptability to different environments (Ba et al., 2016) while $S$. aurita is more sensitive to environmental conditions and is found on the continental shelf in clear and salty waters often reported in waters with salinity $>35$ and temperatures typically below $24{ }^{\circ} \mathrm{C}$ (Camarena, 1986; Fréon, 1988). Although, during the surveys in Senegal salinities have typically been less than this $(\sim 32)$ in surface waters with surface temperatures higher than this $\left(\sim 28^{\circ} \mathrm{C}\right)$ with strong vertical gradients in both parameters. I. africana is mainly encountered in estuarine areas from Senegal to Angola (Whitehead, 1985) in the depth range 0$25 \mathrm{~m}$, with a preferred temperature of $27^{\circ} \mathrm{C}$ (Sanches, 1991; Cheung et al., 2013) while E. fimbriata, occurs in inshore waters, lagoons and more than $300 \mathrm{~km}$ up-stream in rivers e.g. The Gambia River and has been reported to breed throughout the year in waters of highly different salinities (3.5-38), preferring temperatures around $27^{\circ} \mathrm{C}$ (Whitehead, 1985). Warm, low-salinity surface waters, attributed to discharge from the rivers in the area, are generally characteristics of the Casamance and the Gambia coastal areas where occasionally the E. fimbriata are caught in trawls during regular surveys, then often together with I. africana and/or S. maderensis (Krakstad et al., 2005).

No study has been made so far to estimate whether a significant part of the Senegambia pelagic biomass might have been missed by surveys as has been shown for other shallow and inshore areas (Brehmer et al., 2006). This study investigated the inshore distribution of four common clupeid species in Senegambia, E. fimbriata, I. africana, S. maderensis and $S$. aurita using acoustic NASC (nautical area scattering coefficient) data and catch data from two research vessels and literature data from estuarine surveys. The aim of this study was to investigate whether the regular surveys cover the distribution area of these species adequately or if insufficient survey coverage of the shallow shelf areas and estuarine/ riverine systems might introduce bias to the clupeid biomass assessment.

\section{Materials and methods}

Several acoustic surveys have been performed in Senegambia since 1995 within the framework of national or international projects. The general objectives of these surveys were to estimate biomass and map the distribution of the small pelagic fish resources. They took place during the cold season (February to April) or at the end of warm season (October) in the case of the ID, and mainly in October for the DFN (Tab. 1). This study also refers to, and show data from surveys performed in the rivers and estuaries to estimate the abundance of the fish species in these areas, using the shallow boat "Diassanga" (Albaret et al., 2004; Ecoutin et al., 2013; Sadio, 2015). The ID has a smaller draught than the DFN, with an inshore operating depth limit of $10 \mathrm{~m}$ compared to $15-20 \mathrm{~m}$ for the DFN, while the DS is a small wooden catamaran canoe specially designed for shallow water operations.

During all the above surveys (ID and DFN), a common strategy that employed the same sampling protocol was adopted, with systematic parallel course tracks spaced $10 \mathrm{NM}$ (nautical miles) apart, perpendicular to the depth isobaths (Fig. 1). To cover as much as possible of the maximum distribution area of pelagic fish, the shelf was surveyed from Cap Roxo in the south to Saint-Louis in the north, and from the $10 \mathrm{~m}$ (ID) or $15-20 \mathrm{~m}$ (DFN) to $500 \mathrm{~m}$ isobaths. Trawling was done irregularly, either to identify echo registrations or to check 'blindly' whether fish were mixed with the plankton in the upper layers of the water column. A pelagic trawl with floats was used to capture fish close to the surface. A bottom trawl with floats or a smaller pelagic trawl was used to sample pelagic fish in shallow waters (less than $30 \mathrm{~m}$ ). The ID and DFN carry different fishing gear, including differently sized pelagic and demersal trawls. The DS used a $200 \mathrm{~m}$-long purse seine.

Two complementary analyses were performed, first using acoustic data to determine the spatial distribution of the two sardinella species, which is the main target species in the pelagic assessment surveys in Senegambia. This analysis was complemented by using catch data in relation to seabed depth to describe the presence and distribution of the four species targeted in our study.

The ID has few fishing operations $(n=187 ; 2003-2008)$ compared to the DFN ( $n=1320 ; 1981-2006)$, which moreover 
Table 1. Overview of the surveys used, vessels involved (DFN: R/V Dr Fridtjof Nansen, ID: RV Itaf Deme, DS: Diassanga shallow water boat (Albaret et al., 2004; Ecoutin et al., 2013; Sadio, 2015), surveying periods and data available. NASC: Nautical area scattering coefficient $\left(\mathrm{m}^{2} \mathrm{NM}^{-2}\right)$, for sardinella group (SARD = Sardinella aurita and Sardinella maderensis), horse mackerels group (HORS = Trachurus trecae and Caranx rhonchus), other clupeids group (i.e. "P1": including Ethmalosa fimbriata and Ilisha africana) other pelagic fish group (i.e. "P2": other than clupeids and HORS).

\begin{tabular}{|c|c|c|c|c|}
\hline Vessels & Period & Country/Area & Data available & Interest \\
\hline \multirow{2}{*}{$\mathrm{DFN}$} & $\begin{array}{l}\text { Nov } 2005 \\
\text { Nov } 2006\end{array}$ & Senegal and The Gambia & $\begin{array}{l}\text { Pooled NASC data }[20-500 \mathrm{~m}] \text { of SARD, } \\
\text { HORS, P1 and P2 }\end{array}$ & $\begin{array}{l}\text { NASC distribution of both sardinella pooled } \\
\text { Clupeid species occurrence in trawls, position and } \\
\text { depth }\end{array}$ \\
\hline & $\begin{array}{l}\text { Nov } 1981 \text { to } \\
\text { Nov } 2004\end{array}$ & Senegal and The Gambia & $\begin{array}{l}\text { Pooled NASC data }[20-500 \mathrm{~m}] \text { of SARD, } \\
\text { HORS, P1 and P2 }\end{array}$ & $\begin{array}{l}\text { Clupeid species occurrence in trawls, position and } \\
\text { depth }\end{array}$ \\
\hline \multirow[b]{2}{*}{ ID } & $\begin{array}{l}\text { Nov } 2004 \\
\text { Nov } 2005 \\
\text { Nov } 2007\end{array}$ & Senegal and The Gambia & $\begin{array}{l}\text { ID as DFN but with separated NASC } \\
{[10-500 \mathrm{~m}] \text { for } S \text {. aurita and } S . \text { maderensis }}\end{array}$ & NASC distribution of $S$. aurita and $S$. maderensis \\
\hline & $\begin{array}{l}\text { Mar } 2003 \\
\text { Mar } 2004 \\
\text { May } 2005 \\
\text { Nov } 2006\end{array}$ & Only Senegal & $\begin{array}{l}\text { Idem as DFN with separated NASC for } \\
S \text {. aurita and } S \text {. maderensis }\end{array}$ & $\begin{array}{l}\text { Clupeid species occurrence per bottom depth from } \\
\text { trawls }\end{array}$ \\
\hline DS & $\begin{array}{l}2008 \\
2009 \\
2010 \\
2011\end{array}$ & Delta Saloum & $\begin{array}{l}\text { Relative biomass per species ( } 64 \text { species } \\
\text { among which E. fimbriata, S. maderensis, } \\
\text { S. aurita and I. africana) }\end{array}$ & Clupeid species occurrence, position and depth \\
\hline
\end{tabular}

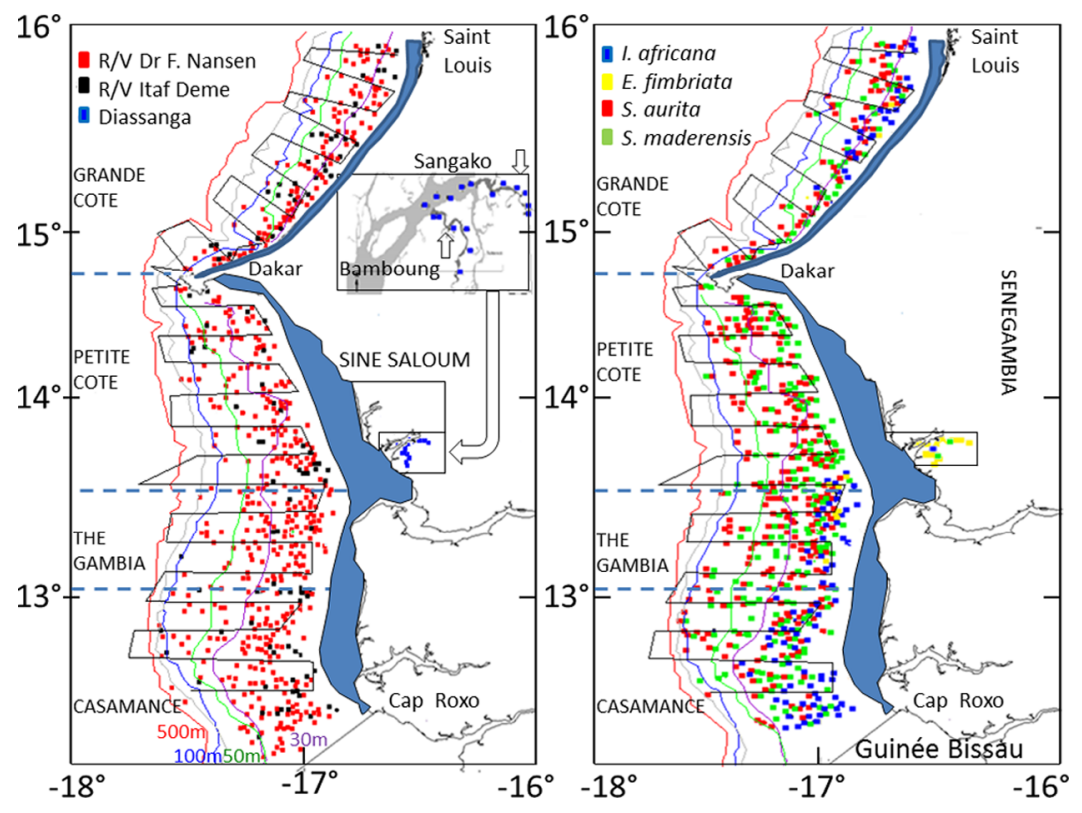

Fig. 1. (a) Map of the study area (Senegambia) and plot of the fishing operations from three vessels: RV Dr Fridtjof Nansen (DFN), RV Itaf Deme (ID) and Diassanga. The zoom shows the localisation of Bamboung and Sangako in Saloum delta (adapted from Sadio and Ecoutin (2013) where the Diassanga led its inshore fishing operations. Acoustic sampling design in parallel transects (DFN and ID) is overlaid in grey line. The isobath lines are shown in red $(500 \mathrm{~m})$, blue $(100 \mathrm{~m})$, green $(500 \mathrm{~m})$ and purple $(30 \mathrm{~m})$. (b) Map of the geographi graphical distribution of Ethmalosa fimbriata, Sardinella aurita, Sardinella maderensis, and Ilisha africana sampled from scientific trawl survey (1981-2006). The total surveyed area $[10-500 \mathrm{~m}]$ is $5600 \mathrm{NM}^{2}$ vs. $1700 \mathrm{NM}^{2}[0-10 \mathrm{~m}]$ not surveyed (shallow part along the coast, in blue).

has provided most regular and standardized data; thus, only fishing operations carried out by the DFN were utilised in this study. The DFN data were analysed by counting the number of trawls containing clupeids from 15 surveys over 25 years, Occurrence and catch rate $\left(\mathrm{kg} \mathrm{h}^{-1}\right)$ from trawl catches were used to analyse the distribution of the clupeid species in relation to bottom depth and to provide an index of catch rates (in kg per hour) per bottom depth interval. Ten meters intervals were used over the whole Senegalese continental shelf $i . e$. the North part (Grande Côte), the Petite Côte (including Saloum delta), The Gambia and the south (Casamance). It has been assumed that these catches, although they were not taken at 
Table 2. Relative abundance of Sardinella aurita, S. maderensis, Ethmalosa fimbriata, Ilisha africana and other species ( $n=56)$ in Saloum delta (Bamboung and Sangako) from 2008 to 2011 (12 surveys; 132 fishing operations) with their abundance (\%Ab.) and biomass (\%Bio.) in percentage (source: Sadio and Ecoutin, 2013).

\begin{tabular}{lllll}
\hline \multirow{2}{*}{ Saloum delta Species } & \multicolumn{2}{c}{ Bamboung } & \multicolumn{2}{c}{ Sangako } \\
\cline { 2 - 4 } & \%Ab. & \%Bio. & \%Ab. & \%Bio. \\
\hline Ethmalosa fimbriata & 79.97 & 37.44 & 33.44 & 22.44 \\
Sardinella aurita & 0.00 & 0.00 & 0.01 & 0.00 \\
Sardinella maderensis & 12.27 & 5.00 & 32.77 & 0.00 \\
Ilisha africana & 1.12 & 1.92 & 33.78 & 0.00 \\
Other species $(n=56)$ & 6.64 & 55.64 & 62.68 \\
\hline
\end{tabular}

random but rather targeted, provide reliable information about the presence of these species, and less robustly, their distribution and abundance in relation to seafloor depth.

During acoustic surveys, NASC (Nautical Area Scattering Coefficient) values, representing reflected sound energy from fish and plankton in the water column, were recorded using an Simrad EK500. The echosounder was connected to a drop keel mounted (DFN) or hull mounted (ID) Simrad ES38B transducer $(38 \mathrm{kHz})$ used for standard biomass estimation on-board ID and DFN. See e.g. Krakstad et al. (2005). The echosounders were sphere calibrated according to standard procedures at least once a year. See Krakstad et al. $(2005,2006)$ for details of echosounder settings and calibration results. Recorded NASC values were scrutinized using the BEI system (DFN) or BI500 (ID). During this process NASC recordings were allocated to individual specified target groups based on a combination of visual scrutiny of the behaviour pattern as deduced from echograms and the compositions of the catches. Target groups used onboard DFN was Sardinella; $S$. aurita and $S$. maderensis, Horse mackerel; T. trecae and $T$. Trachurus, PEL1 (Pelagic fish type 1) I. africana and other clupeoid fish species, PEL2 (Pelagic fish type 2); other carangids than horse mackerel, Scombrids, Shyraenids and Trichiurids. These target groups have been chosen based on their acoustic characteristics and are standard groups used during DFN surveys. The resulting datasets were stored by $5 \mathrm{NM}$. ID used similar grouping but separated the two sardinella NASC in the same ratio as their contribution to the mean back-scattering strength in the length frequency samples during scrutinizing. The discriminated (ID) sardinella acoustic data were analysed for the surveys including The Gambia (2004, 2005 and 2007), and distinct bathymetric fish-density distributions were calculated according to their NASC values, averaged over $1 \mathrm{NM}$ intervals, excluding values recorded between transects (latitudinal inter-transects), plotted against seafloor depths and mapped. From the DFN NASC data analyses, the distribution of pooled Sardinella sp. in relation to seabed depth were analysed for the last two surveys (2005 and 2006) of the time series which were re analysed by deleting all inter-transects parallel to the coastline. All the acoustic data used (ID and DFN) are from surveys of the same season (November).

From the literature, we added data obtained by the Diassanga (DS), which partially covered the Saloum delta (Guillard and Lebourges, 1998; Sow and Guillard, 2010; Sadio, 2015). During these DS research cruises, fish samples were taken with a $200 \mathrm{~m}$ purse seine ( 12 surveys: $n=132$ purse seine operations, split into 60 operations in Bamboung and 72 operations in Sangako). We used these earlier efforts to list the main Saloum species. The NASC fish distribution, analysed through BI500 (Knudsen, 1990) and LSSS (Korneliussen et al., 2006) software, are mapped using Surfer ${ }^{\circledR} 8$ (Golden Software, LLC) and the surface covered by the acoustic sampling scheme are estimated using Survey Mapper software (Pers. Comm. Marek Ortrowski (IMR) 2004) starting from the coastline to $10 \mathrm{~m}$ bottom depth for the shallow area and to $500 \mathrm{~m}$ depth for the whole continental shelf.

\section{Results}

\subsection{Distribution of Clupeids in relation to seafloor depth}

Approximately $5300 \mathrm{NM}^{2}$ was surveyed annually between Cap Roxo (Casamance) and the Cap-Vert peninsula (Dakar) by both vessels, plus $1140 \mathrm{NM}^{2}$ between the Cap-Vert peninsula and Saint-Louis (Grande Côte) by the DFN. Between the coastline and offshore waters deeper than $10 \mathrm{~m}$, we estimated an area of approximately $1500 \mathrm{NM}^{2}$ along the Petite Côte, where no previous abundance survey had been performed (for the ID) and $200 \mathrm{NM}^{2}$ for the Grande Côte, representing 20\% and $3 \%$ of the total surface area, respectively (Fig. 1a). A total of 1320 trawl hauls were carried out by DFN in the study area, of these 496 stations contained the four clupeid species targeted in this study.

The DS catch data covering the Saloum delta confirm that S. maderensis, E. fimbriata and I. africana were distributed all the way into the delta far inshore of the area surveyed by the DFN or ID (Fig. 1b). A total of 60 fish species were registered in the Saloum delta where $S$. aurita is virtually absent from the DS catches, although a few individuals were recorded in Sangako (Tab. 2). S. maderensis was the second most frequent species in the Saloum $(12 \%$ of the total) after E. fimbriata (79\%).

The maps of sardinella distribution separated (ID) based on recorded NASC values show the spatial distribution of this species (Fig. 2). The maps indicate that the main concentration of $S$. aurita is found on the central part of the shelf off the Gambia and Saloum River, with only few registrations in the southern part of the Casamance shelf and with densities declining towards the inshore part of the survey area. The main distribution of $S$. maderensis is further inshore and southwards than that of $S$. aurita with main concentrations on the Casamance shelf and the Gambia. The distribution map also 


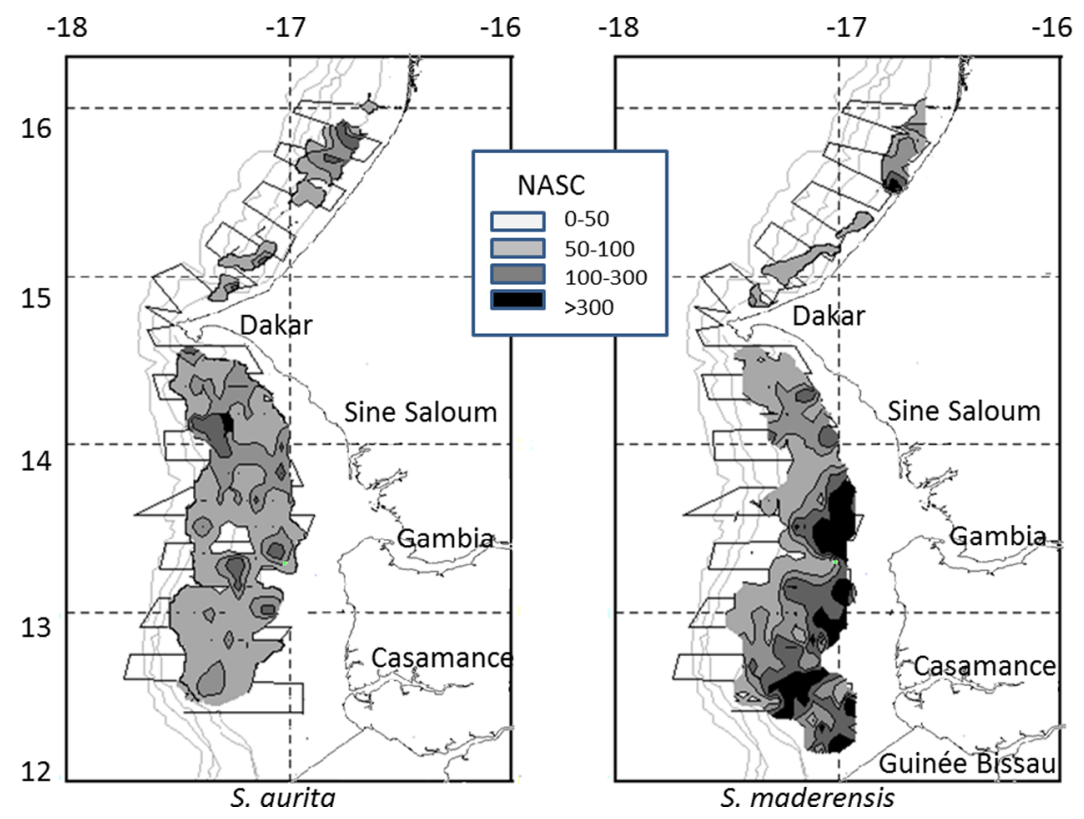

Fig. 2. Distribution maps of Sardinella aurita and S. maderensis (in NASC: Nautical area scattering coefficient $\left(\mathrm{m}^{2} \mathrm{NM}^{2}\right)$ ) from the three acoustic surveys of RV Itaf Deme covering the whole continental shelf of Senegal and the Gambia (Senegambia; 2005-2006-2007).

indicates that relatively high concentrations were extending southwards into Guinea Bissau.

From the DFN acoustic data, the average NASC recorded increased towards shallower waters and some annual variability in the distribution of sardinella was noted (Fig. 3a, DFN). Sardinella were distributed with higher NASC values further inshore in 2005. That year in particular there were no signs of biomass decreasing towards the inshore limit of the survey area i.e. less than $20 \mathrm{~m}$ bottom depth for the DFN.

The data from the ID covering shallower depths [10-19 m] and discriminating the two Sardinella species, showed that their NASC distributions were different (Fig. 3a, ID). The abundance of $S$. aurita generally dropped towards 0 at around $10 \mathrm{~m}$ bottom depth and was at its greatest at a seafloor depth range of 35-49 m. However, the ID data also suggest that the abundance of $S$. maderensis continued to increase towards the $10 \mathrm{~m}$ isobath. Higher NASC offshore (Fig. 3a, DFN), at bottom depths of 50-120 m, are mainly due to $S$. aurita, verified with catch data (Fig. 4). No sardinella were recorded in either dataset (DFN and ID) beyond the $120 \mathrm{~m}$ isobath.

The map of occurrence, which also shows the positions of trawl catches of the four clupeid species by the DFN (19812006) (Fig. 1b) together with the histogram of distribution of catch rates relative to seafloor depth for the four species (Fig. $3 b$ ), shows their spatial distribution. These maps show the offshore distribution boundaries of $I$. africana (approx. $60 \mathrm{~m}$ bottom depth) and E. fimbriata (approx. $20 \mathrm{~m}$ ). E. fimbriata was only found off The Gambia (Fig. 1b), while I. africana was also distributed further south and is abundant in the Casamance area. Neither E. fimbriata nor I. africana were identified by the DFN surveys between the Saloum River and Cap Vert peninsula.

The average catch rates of both sardinella species fell in shallow waters. S. aurita declined rapidly from a modal peak at $45 \mathrm{~m}$ while $S$. maderensis displayed a slower decline from a less pronounced modal peak around $30 \mathrm{~m}$ (Fig. 3b). Catch rates also fell to 0 in the offshore direction, with $S$. maderensis encountered in areas with bottom depths of less than $80 \mathrm{~m}$ on the shelf, while scattered catches were also made off the shelf. $S$. aurita has a more pronounced offshore distribution, with catches averaging $100 \mathrm{~kg} \mathrm{~h}^{-1}$ to $100 \mathrm{~m}$ bottom depth (Fig. 3b) and scattered catches in areas beyond this isobath. On the Casamance shelf, I. africana is well distributed (Fig. 1b). The map also shows that the distribution of $I$. africana extended southwards into Guinea Bissau and that the species is also found off the Saloum delta. E. fimbriata was only found within $20 \mathrm{~m}$ isobath in the DFN catches i.e. in the shallowest catches of the DFN.

From the relative proportions of $S$. aurita and $S$. maderensis in the DFN catches, the proportion of $S$. aurita, by weight approached 0 per cent at around $15 \mathrm{~m}$ bottom depth. Although some individual fish appeared in around $25 \%$ of the trawl hauls (Fig. 4). The proportion of S. maderensis likewise fell further offshore at around $60 \mathrm{~m}$ bottom depth, although there were some individuals in hauls at greater depths.

\section{Discussion}

Our analyses show that data from the three research vessels do not offer a complete overview of the distribution of the four main clupeids over the Senegambia continental shelf. Acoustic and catch data were used as ground-truthing information in this study, and each of them may have some limitations. The DFN acoustic database is large, but is limited by lack of separate NASC data for each of the four species. However, the ID acoustic data covering the whole Senegambian shelf over three surveys significantly contribute to fill this gap and provide reliable information of the specific distribution of the two sardinella lack. Catch data provide less accurate information about distribution but are reliable as regards presence of the 
(a)

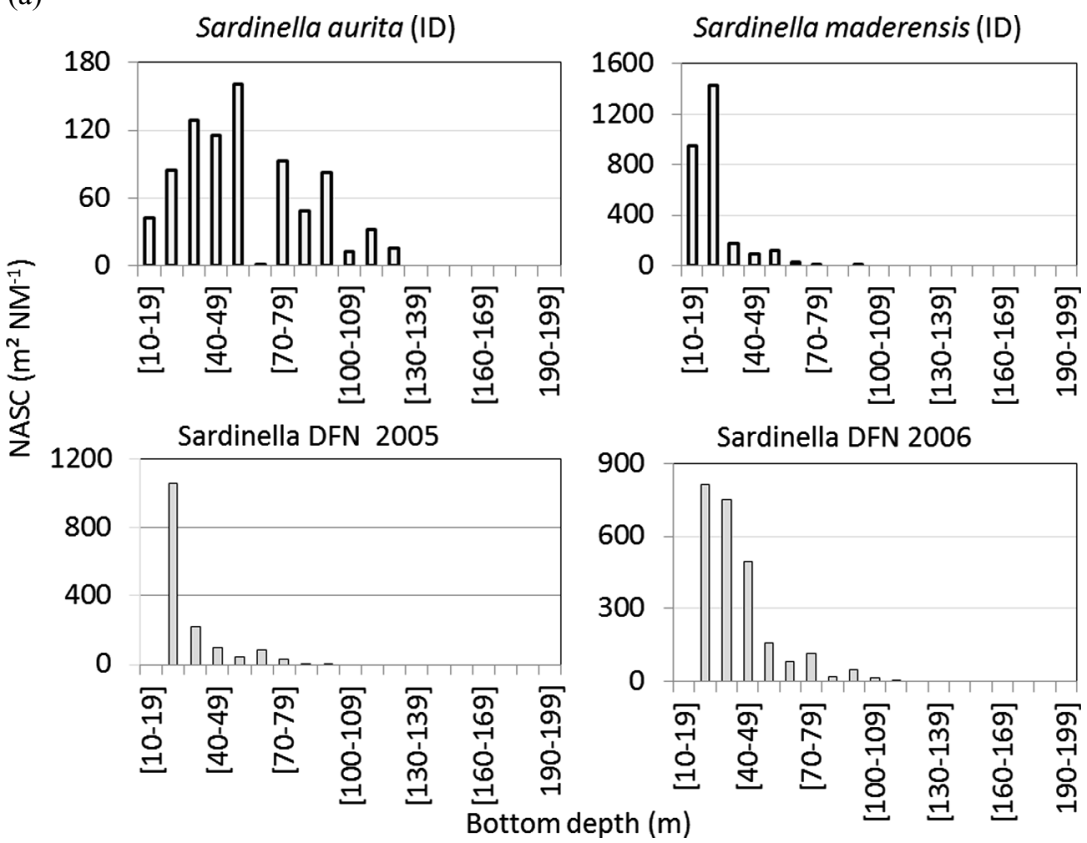

(b)

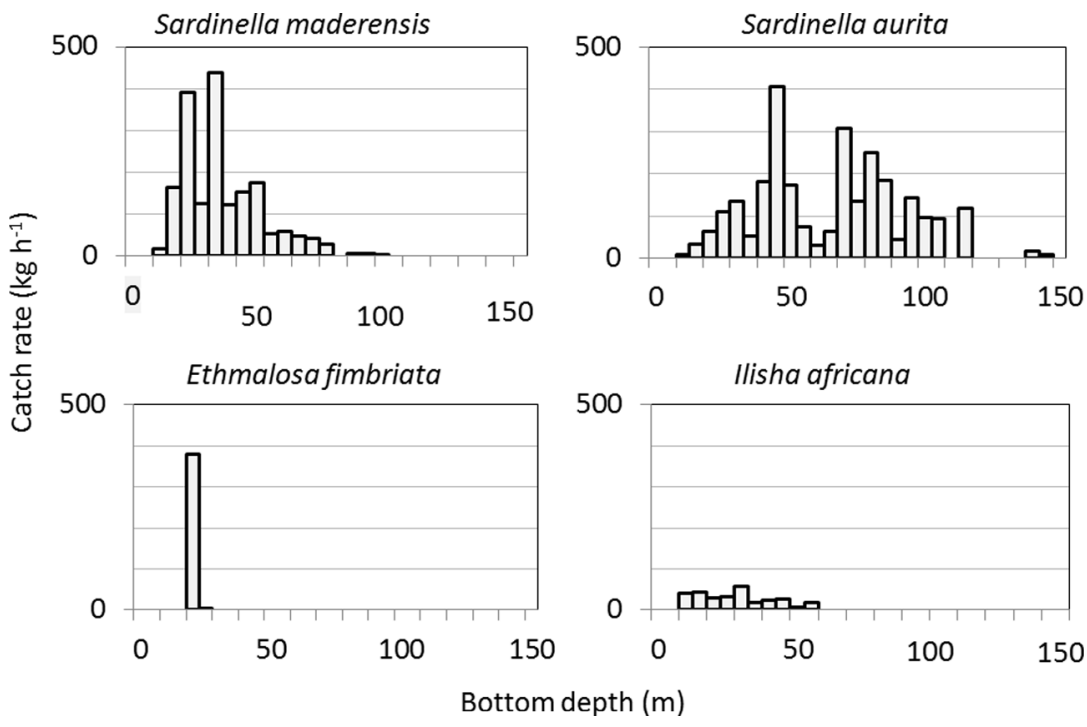

Fig. 3. Histograms of the (a) bottom depth distribution of the NASC of Sardinella aurita and S. maderensis from the RV Itaf Deme "ID" (acoustic small pelagic assessment survey covering the Senegambia led in 2004, 2005, and 2007) and pooled NASC of both sardinella from the RV Dr Fridtjof Nansen "DFN" (acoustic small pelagic assessment survey led in 2005 and 2006 with sample (10-19 m) missing); (b) bottom depth distribution of relative catch rates of $S$. aurita, S. maderensis, Ethmalosa fimbriata and Ilisha africana, from the DFN trawl operation time series $(1981-2006 ; n=1320)$.

species. The vast DFN catch database provided a valuable input in this regard. Only catch data from the research vessels which covered the area were used in our analyses and more data from smaller (commercial) fishing vessels operating on the inner part of the shelf would probably have strengthened our results. However, data available from this small-scale fleet are heavily biased by its targeting of $S$. aurita, which is commercially more valuable than $S$. maderensis, and is probably also biased by the higher avoidance reaction of fish in shallow water to these vessels. Moreover, these data are not geo-localized and the station depths are not specified.

\subsection{The case of Ethmalosa fimbriata}

Registrations of E. fimbriata from the DFN surveys are few: the species is distributed in the shallow coastal waters, mainly where the seafloor depth is less than $20 \mathrm{~m}$. The few registrations off The Gambia were mainly made at bottom depths of between 15 and $20 \mathrm{~m}$, with only one registration deeper than $20 \mathrm{~m}$ (Fig. 2). This inshore distribution extends inside the Saloum estuary (Tab. 2). The extended offshore distribution off The Gambia may be due to the flooding from The Gambia River, which provides favourable environmental 


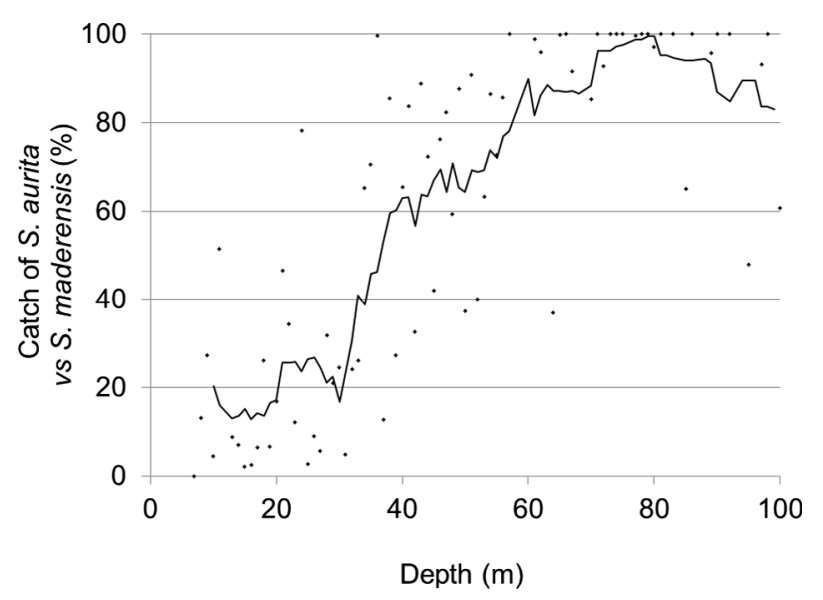

Fig. 4. Relative proportion per bottom depth of Sardinella aurita in comparison with $S$. maderensis from RV Dr Fridtjof Nansen catches (black line: 8-moving average, and associated raw data in black diamond dots) within Senegambia from 1981 to 2006 ( $n=1320$ trawl operations).

conditions with among others lower salinity than the Saloum delta.

\subsection{The case of Ilisha africana}

I. africana was found towards the south of the survey area, with main concentrations on the Casamance shelf, extending toward Guinea Bissau and a horizontal distribution offshore to around $60 \mathrm{~m}$ bottom depth, increasing towards the shallowest seafloor depth (15-20 m) sampled by the DFN (Fig. 2). No marked decreasing trend in the registered concentrations is observed towards the coast and these concentrations overlap roughly with the shelf areas surveyed by the DFN with minimum surface salinity, maximum temperature and relatively high species diversity (Krakstad et al., 2005; Krakstad et al., 2006). This species is known to have a great capacity for osmoregulation and sustain a wide range of salinities such as those in the hyperhaline Saloum delta, where values can reach 36 during the dry season and drop far below seawater values during the rainy season (Simier et al., 2004), and with their widest distribution during periods of maximum salinity (highest marine influence) in The Gambia River, where they also spawn (Vidy et al., 2004). We assume that I. africana was not well covered by conventional acoustic survey methods, due to what were probably high concentrations in the shallow part of the shelf (0-10 $\mathrm{m}$ bottom depth).

\subsection{The case of sardinella}

The distribution of S. aurita appears to have been covered adequately during both surveys on board DFN and ID, according to both acoustic and catch data. The acoustic data showed a typical distribution of $S$. aurita from $10 \mathrm{~m}$ down to $120 \mathrm{~m}$, while the depth distribution of their captures was slightly less extensive, from 15 to $100 \mathrm{~m}$ bottom depth, with the highest concentrations in both analyses around the $50 \mathrm{~m}$ isobath, and a modal peak in catch size at around $35-45 \mathrm{~m}$ (Fig. 2). In this area, S. aurita was mixed with $S$. maderensis in similar densities ( $40 \%$ to $60 \%$, Fig. 4). Further offshore, i.e., in layers above seafloor depths of more than $50 \mathrm{~m}, S$. aurita becomes dominant with only occasional mixing with $S$. maderensis (Fig. 4). The distribution of $S$. aurita was generally further offshore and further north than for $S$. maderensis (Fig. 2). Concentrations of $S$. aurita decreases towards areas with minimum surface salinity and maximum surface temperature (Krakstad et al., 2005, 2006). S. aurita have been reported as far inshore as the mouth of the Saloum estuary (Albaret et al., 2004; Simier et al., 2006) but recordings were few and the results of the present study indicate that it was not abundant in shallower bottom depths than those surveyed by the DFN.

The distribution of $S$. maderensis may not have been covered adequately by the DFN or even the ID surveys. The average NASC of the DFN allocated to sardinella increases towards the coast. Moreover, at $20 \mathrm{~m}$ bottom depth about $80 \%$ (Fig. 4) of the sardinella caught were S. maderensis. In all the years surveyed, there was also an increase in their density towards the coast, and there was no clear trend in the direction of a reduction in NASC towards the end of transects (Fig. 3a). Trawl catch data somewhat contrast these observations and indicate that the main concentrations of $S$. maderensis were found between 15-40 $\mathrm{m}$ bottom depth and that catches of that species were smaller closer to the shore. The concentrations increase towards areas with minimum surface salinity and maximum surface temperature (Krakstad et al., 2005, 2006), and the inner part of the distribution covered by the survey overlaps with that of I. africana. S. maderensis was particularly abundant in the Saloum estuary (Albaret et al., 2004; Sadio, 2015) and in The Gambia River (Vidy et al., 2004) (Fig. 2). The tendency to congregate at shallow bottom depths was confirmed by the similar species abundance found in Saloum (Tab. 2).

\subsection{Implications for biomass estimation of the clupeids}

Neither of the estuarine species of marine origin $E$. fimbriata or I. africana (Albaret et al., 2004) were picked up by the DFN surveys along the Senegambia area north of Saloum delta. We assume that both species are more closely associated with inshore systems and do not move up the coast away from the rivers. Knowledge of differences in fish distribution patterns is essential for biomass estimation of pelagic fish species using acoustic methods (Simmonds and MacLennan, 2005). It is assumed from this study that the DFN surveys cannot expect to pick up abundance trends in the populations of E. fimbriata and I. africana during the assessment surveys. In The Gambia estuary, E. fimbriata and the I. africana were the most abundant of 70 fish species inventoried, with stocks of more than 500000 and 100000 tonnes, respectively (Albaret et al., 2004). They are followed at fourth place by $S$. maderensis with 66000 tonnes, while $S$. aurita was not even listed among the 70 species inventoried. The total absence of $S$. aurita in this inventory might be due to its highly developed ability to avoid fishing gear (Brehmer, 2004), but a very low abundance is very likely.

Sardinella were the target species of the DFN and ID assessment surveys. S. aurita seems to be covered adequately by the surveys and probably only small proportions within the 


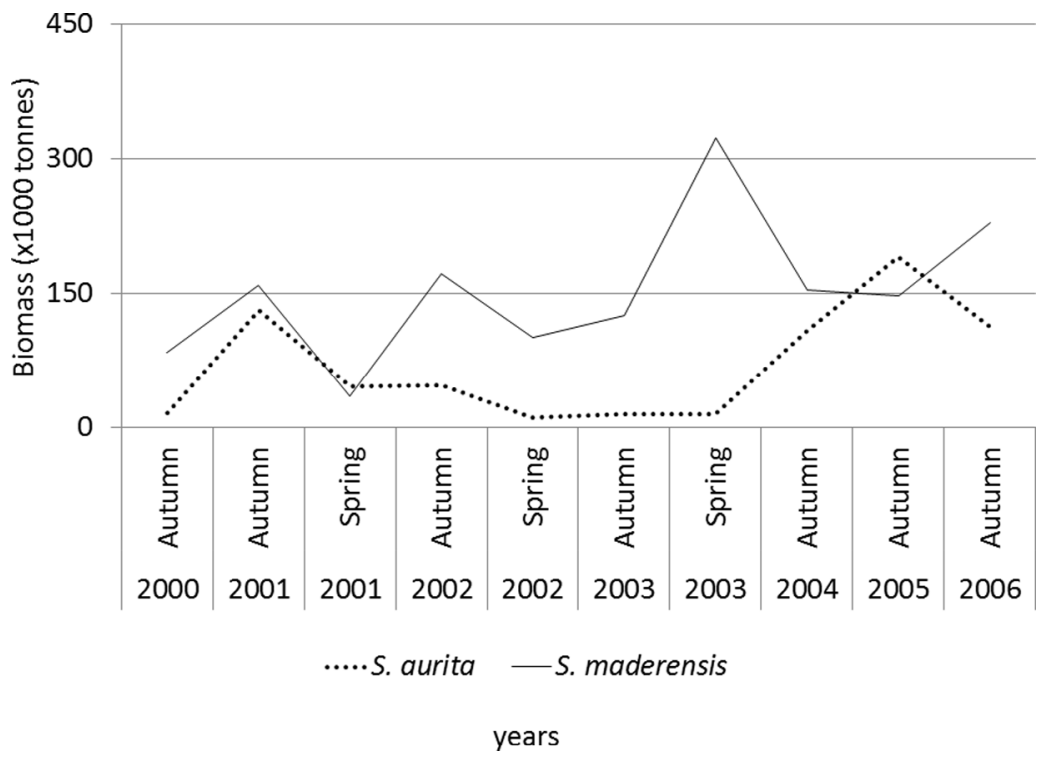

Fig. 5. Biomass estimates of Sardinella aurita and S. maderensis from DFN surveys in the continental shelf between Casamance and Cape-Vert in thousand tonnes, from 2000 to 2006, on autumn and spring seasons.

surveyed area escape (Figs. 2-4). However, the distribution of $S$. maderensis, which is a marine-estuarine species (Albaret et al., 2004), was shown to extend well inshore of the area surveyed by DFN. The average fish density per bottom depth interval (Fig. 3a) in 2005 and 2006, also displayed differences in how far inshore sardinella were distributed, which suggests that the proportion missed may differ from year to year, as it does in the Gulf of Lion in the south of France where a similar effect has been reported by Brehmer et al. (2006) for other small pelagic fish including clupeids (i.e. Sardina pilchardus, engraulidae). There is a seasonality in the distribution of $S$. maderensis in the river systems discussed here, as sardinella numbers fell during the survey period (end of October) i.e. at the end of the wet season (Albaret et al., 2004; Guillard et al., 2004), and there is a lower frequency of fish schools close to the coast. The estuaries are mainly used as nursery grounds for fry and juvenile fish, particularly by clupeids (Albaret et al., 2004; Vidy et al., 2004); such size classes were not included in the biomass estimates made by the DFN or ID. Obviously, in areas shallower than $10 \mathrm{~m}$, the volume of water (i.e. the pelagic habitat) the fish can use decreases rapidly because of decreasing water depths towards the coast. It is therefore to be expected that abundance, or at least density per $\mathrm{m}^{2}$, declines towards the coast in very shallow water $(0-5 \mathrm{~m})$ and the shape of the declining NASC curve is likely to be sigmoid. We can assume that the reduced available depth of the habitat causes the fish to spread out over a wider horizontal area, and thereby maintaining high biomass even in shallow regions. This could partly explain the high number of observations in shallow waters and should still be investigated further as done in Mediterranean Sea using a shallow boat (Brehmer et al., 2006). Looking at the NASC recordings from ID (Fig. 3a) it seems that the abundance of $S$. maderensis continued to increase inside the area that cannot be surveyed by the DFN (i.e. shallower than $15 \mathrm{~m}$ bottom depth).

We therefore conclude that the biomass missed each year was variable, and in this area may be considerable for both $E$. fimbriata and I. africana. Further studies should be carried out to obtain more knowledge of the spatio-temporal distribution of $S$. maderensis in shallow waters, although acoustic surveys limited to a minimum depth of $15 \mathrm{~m}$ cannot fully cover the stock. Our estimates of this species although considerable, (averaging 450000 tonnes in the period 2000-2006, DFN estimates) must be considered minimum estimates. The continental shelf between Casamance and Cape-Vert in many ways is a worst-case scenario for conventional small pelagic assessment surveys, because the inshore unsurveyable area comprises $20 \%$ of the total continental shelf. In this area, the DFN sardinella biomasses as yielded from the different surveys showed a relative variability in abundance as illustrated in Figure 5. This biomass index shows the relatively low abundance of $S$. aurita compared with $S$. maderensis, and spring yielded biomass compared to autumn estimates.

\subsection{The challenge of surveying shallow water areas}

It is clear that abundance surveys of fish stocks in shallow water lagoons, estuaries and lakes are subject to several problems (Brehmer et al., 2011). Traditional offshore survey vessels are inevitably too large to cover these areas (Brehmer et al., 2006), and small speedboats face human and logistical problems. Consequently, large shallow shelf areas are difficult to cover. In fact, even regular offshore surveys are already difficult to maintain in Senegambia due to financial constraints. However, small boats may still be the essential tools when focus is on the abundance and ecology of the coastal ecosystems. Complementary knowledge on fish exchange between the estuaries and the shelf could help identify both the best period to survey the offshore areas, and identify how large proportion of the stock is really missed during these offshore surveys. A recent approach developed in the last ten to fifteen years is airborne LIDAR (Light Detection and Ranging) which measures distance to a target by illuminating it with a pulsed laser light and measuring the reflected pulses. This technique is 
in many aspects similar to echo sounding; it has a range of around $40 \mathrm{~m}$ depth depending on the degree of turbidity and has no minimum depth threshold (Churnside et al., 2001). The use of aircraft has some clear advantages over vessels in shallow water surveys, as they require a very small crew while covering large survey areas in a relatively short time span. Aircraft are therefore very cost-effective in comparison with vessels. The coast of North West Africa, and particularly the shallow water areas of the Banc D'Arguin in Mauritania and the inner shelf between Cape Vert and Casamance would be a good places to test such techniques in Africa, and in combination with ground truthing of scientific catches or video observations from speedboats, could greatly increase the available information regarding the distribution and abundance of pelagic species in these shallow waters, effectively complementing classical acoustics assessments, which provide reliable standardised time series.

Acknowledgements. This work was supported by the "Nansen Programme", funded by Norad and the United Nations Food and Agricultural Organization. The authors are grateful to the research vessel crews and colleagues who participated in the surveys, as well as the joint CRODT-IRD team for their contributions to the acquisition of estuarine data. We also thank the AWA project funded by IRD, the PREFACE Project ID: 603521, Funded under FP7-ENVIRONMENT by the European Commission and the BMBF (grant 01DG12073E) implemented by the Sub-Regional Fisheries Commission (SRFC/CSRP, Dakar), for data analysis support. We dedicate this work to Ibrahima Sow re-CRODT, who led the Saloum survey with the IRD team. We gratefully thank anonymous reviewers for their advices.

\section{References}

Albaret JJ. 1987. Les peuplements de poisons de la Casamance (Senegal). Rev Hydrobiol Trop 20: 291-310.

Albaret JJ, Simier M, Darboe FS, Ecoutin JM, Tito de Morais L. 2004. Fish diversity and distribution in the Gambia Estuary, West Africa, in relation to environmental variables. Aquat Living Resour 17: 35-46.

Auger P-A, Gorgues T, Machu E, Aumont O, Brehmer P. 2016. What drives the spatial variability of primary productivity and matter fluxes in the north-west African upwelling system? A modelling approach. Biogeosciences 13: 6419-6440.

Ba K, Thiaw M, Lazar N, Sarr A, Brochier T, Ndiaye I, Faye A, Sadio O, Panfili J, Brehmer P. 2016. Resilience of key biological parameters of the Senegalese flat sardine in the context of overfishing and climate change. Plos one 11: e0156143.

Brehmer P. Comparative analysis of dynamical and spatial characteristics of fish schools Sardinella aurita: behavioral adaptations to environment and exploitation; effect on the catchability, $\mathrm{PhD}$ thesis 3733 Ensar, Rennes, 2004.

Brehmer P, Do Chi T, Mouillot D. 2006. Amphidromous fish school migration revealed by combining fixed sonar monitoring (horizontal beaming) with fishing data. J Exp Mar Biol Ecol 334: 139-150.

Brehmer P, Guillard J, Guennegan Y, Bigot J, Liorzou B. 2006. Evidence of a variable "unsampled" pelagic fish biomass in shallow water $(<20 \mathrm{~m})$ : the case of the Gulf of Lion. ICES J Mar Sci 63: 444-451.
Brehmer P, Do chi T, Laugier T, Laloë F, Darnaude AM, Fiandrino A, Mouillot D. 2011. Field investigations and multi-indicators for shallow water lagoon management: perspective for societal benefit. Aquat Conserv 21: 728-742.

Camarena LT. Les principales espèces de poissons pélagiques côtiers au Sénégal: biologie et évaluation des ressources, Doctoral dissertation, Universite de Bretagne Occidentale, Brest, France, 1986, $187 \mathrm{p}$.

Cheung WL, Watson R, Pauly D. 2013. Signature of ocean warming in global fisheries catch. Nature 497: 365-368.

Churnside JH, Wilson J, Tatarskii V. 2001. Airborne Lidar for fisheries applications. Opt Eng 40: 406-414.

Diouf PS. Les peuplements de poissons des milieux estuariens de l'Afrique de l'Ouest: l'exemple de l'estuaire hyperhalin du Sine Saloum, Orstom Edition, Thèses et Documents 156, Université de Montpellier 2, 1996, $303 \mathrm{p}$.

Ecoutin JM, Béhagle N, Brochier T, Guillard J, Laë R, Lebourges DA, Le Loc'h F, Raffray J, Sadio O, Simier M, Sow I, Tito de Morais L. L'aire marine protégée communautaire de Bamboung (Sine Saloum): synthèse 2003-2011, IRD, Dakar, 2013, pp. 77-97.

Fame EU, Njoku UG, Ogueji EO, Ifeanyichukwu C, Stanley IC, Mbah CE, Ibrahim BUB. 2017. Analysis of technical efficiency of three fish processing methods and proximate assay on Ilisha Africana (Bloch, 1795). Int J Food Sci Nutr 2: 154-158.

Fréon P. Réponses et adaptations des stocks de clupeides d'Afrique de l'Ouest à la variabilité du milieu et de l'exploitation: analyse et réflexion à partir de l'exemple du Sénégal, Études et thèses, ORSTOM, Paris, 1988, 287 p.

Guillard J, Lebourges DA. 1998. Preliminary results of fish population distribution in a Senegalese coastal area with depths less than 15 m, using acoustic methods. Aquat Living Resour 11: $13-20$.

Guillard J, Albaret JJ, Simier M, Raffray J. 2004. Spatio-temporal variability of fish assemblages in The Gambia Estuary (West Africa) observed by two vertical hydroacoustic methods: Moored and mobile sampling. Aquat Living Resour 17: 47-55.

Jallow AM. 1994. Utilization of bonga (Ethmalosa fimbriata) in West Africa, FAO Fisheries Circular No. 870, Rome, 28 p.

Knudsen HP. 1990. The Bergen Echo Integrator: an introduction. $J$ Cons Int Explor Mer 47: 167-174.

Korneliussen RJ, Ona E, Eliassen I, Heggelund Y, Patel R, Godø OR, Lien G. The Large Scale Survey System - LSSS, Presented at the Proceedings of the 29th Scandinavian Symposium on Physical Acoustics, Ustaoset, 2006.

Krakstad JO, Sylla S, Jallow J, Olsen M. Survey of the pelagic fish resources off north west Africa, Institute of Marine Research, Bergen, Nansen survey report Part I: Senegal, NORAD-FAO Project GCP/INT/730/NOR, 2005, 67 p.

Krakstad JO, Olsen M, Sarré A, Mbye EM. Survey of the pelagic fish resources off north west Africa, Institute of Marine Research, Bergen, Nansen survey report Part I: Senegal, NORAD-FAO project GCP/INT/730/NOR, 2006, 54 p.

Ndoye S, Capet X, Estrade P, Dagorne D, Sow BA, Gaye AT, Brehmer P. 2014. Sea Surface temperature 'SST' patterns and dynamics of the southern Senegal-Gambia upwelling center. J Geophys Res 119: 8315-8335.

Panfili J, Durand JD, Mbow A, Guinand B, Diop K, Kantoussan J, Thior D, Thiaw TO, Albaret JJ, Lae R. 2004. Influence of salinity on life history traits of the bonga shad Ethmalosa fimbriata (Pisces, Clupeidae): Comparison between The Gambia and Saloum estuaries. Mar Ecol Prog Ser 270: 241-257. 
Roy C, Cury P, Kifani S. 1992. Pelagic fish recruitment success and reproductive strategy in upwelling areas: environmental compromises. S Afr J Mar Sci 12: 135-146.

Sadio O. Evaluation de l'efficacité des Aires Marines Protégées comme outil de la restauration des ressources marines et de gestion des stocks halieutiques: l'expérience ouest africaine, $\mathrm{PhD}$ Thesis, Univeristé de Bretagne Occidental UBO/EDSM, Brest, 2015.

Sadio O, Ecoutin JM. Comparaison du peuplement de Bamboung avec celui d'un site autorisé à l'exploitation halieutique le bolon de Sangako, in: J.M. Ecoutin, N. Béhagle, T. Brochier, J. Guillard, R. Laë, A.L. Dhaussy, F. Le Loc'h, J. Raffray, O. Sadio, M. Simier, I. Sow, L.T. de Morais (Eds.), L'aire marine protégée communautaire de Bamboung (Sine Saloum): synthèse 2003-2011, IRD, Dakar, 2013, pp. 77-97.

Sanches JG. 1991. Catálogo dos principais peixes marinhos da República de Guiné-Bissau. Publ Avuls Inst Nac Invest Pescas 16: 429 p.

Simier M, Blanc L, Aliaume C, Diouf PS, Albaret JJ. 2004. Spatial and temporal structure of fish assemblages in an 'inverse estuary', the Sine Saloum system (Senegal). Estuar Coast Shelf Sci 59: 69-86.

Simier M, Laurent C, Ecoutin JM, Albaret JJ. 2006. The Gambia River estuary: A reference point for estuarine fish assemblages studies in West Africa. Estuar Coast Shelf Sci 69: 615-628.

Simmonds J, MacLennan DN. Fisheries Acoustics: theory and practice, Vol. 10, 2nd edition, Willey-Blackwell, London, 2005.
Sloterdijk H, Brehmer P, Sadio O, Müller H, Döring J, Ekau W. 2017. Composition and structure of the larval fish community related to environmental parameters in a tropical estuary impacted by climate change. Estuar Coast Shelf Sci 197: 10-26.

Sow I, Guillard J. 2010. Suivi par hydroacoustique du peuplement piscicole d'une Aire Marine Protégée du Sine-Saloum (Sénégal): bilan 2003-2007. J Sci Hal Aquat 1: 21-32.

Surfer $^{\circledR} 8$ from Golden Software, LLC (www.goldensoftware.com)" 809 14th Street Golden, Colorado 80401.

Thiaw M, Auger P-A, Sow F, Brochier T, Faye S, Diankha O, Brehmer P. 2017. Effect of environmental conditions on the seasonal and inter-annual variability of small pelagic fish abundance off North-West Africa: the case of Senegalese sardinella S. aurita (round sardinella) and S. maderensis (flat sardinella). Fish Oceano 26: 583-601.

Tiedemann M, Brehmer P. 2017. Larval fish assemblages across an upwelling front: Indication for active and passive retention. Estuar Coast Shelf Sci 187: 118-133.

Vidy G, Darboe FS, Mbye EM. 2004. Juvenile fish assemblages in the creeks of the Gambia Estuary. Aquat Living Resour 17: 56-64.

Whitehead PJP. 1985. Clupeoid fishes of the world (suborder Clupeoidei). An annotated and illustrated catalogue of the herrings, sardines, pilchards, sprats, shads, anchovies and wolf-herrings. Rome, FAO Species Catalogue. Vol. 7. Fish Synop 125: 1-303.

Cite this article as: Sarré A, Krakstad J-O, Brehmer P, Mbye EM. 2018. Spatial distribution of main clupeid species in relation to acoustic assessment surveys in the continental shelves of Senegal and The Gambia. Aquat. Living Resour. 31: 9 